\title{
Pengaruh Gerhana Matahari Terhadap Nilai Percepatan Gravitasi Bumi: Sarana Pembelajaran untuk Mendekatkan Fisika pada Kehidupan Sehari- hari
}

\author{
Toni Kus Indratno ${ }^{1,2}$, Ginanjar A. Muhammad ${ }^{1,2}$, dan Widiyaka Adinugraha ${ }^{1}$ \\ IProgram Studi Pendidikan Fisika Universitas Ahmad Dahlan \\ ${ }^{2}$ Pusat Studi Astronomi Universitas Ahmad Dahlan \\ J1. Prof. Dr. Soepomo, SH., Janturan, Umbulharjo, Yogyakarta \\ Surat-e: tonikus@staff.uad.ac.id
}

\begin{abstract}
Gerhana matahari merupakan fenomena alam yang jarang terjadi. Peristiwa ini akan terjadi berulang setiap 350 tahun sekali pada tempat yang sama. Gejala ini terjadi saat matahari, bulan, dan bumi terletak pada satu garis lurus, sehingga cahaya matahari terhalang oleh bulan. Pada tanggal 9 Maret 2016 yang lampau, Indonesia merupakan negara satu-satunya yang dilewati oleh jalur Gerhana Matahari Total (GMT). Telah dilakukan pengukuran percepatan gravitasi bumi saat terjadi gerhana. Eksperimen ini dilakukan untuk melakukan verivikasi terhadap teori, bahwa percepatan gravitasi bumi akan berkurang nilainya saat terjadi gerhana. Eksperimen ini dilakukan dengan metode Microcomputer Based Laboratory (MBL). Dari data yang diperoleh, didapati bahwa terjadi penurunan percepatan gravitasi saat terjadi gerhana. Sebelum gerhana percepatan gravitasi sebesar $9,78 \mathrm{~m} / \mathrm{s}^{2}$. Saat kontak pertama matahari dan bulan percepatan gravitasi sebesar $9,45 \mathrm{~m} / \mathrm{s}^{2}$, saat puncak gerhana $8,87 \mathrm{~m} / \mathrm{s}^{2}$, dan saat kontak terakhir $9,60 \mathrm{~m} / \mathrm{s}^{2}$. Penurunan terbesar saat puncak gerhana yang mencapai $9,45 \%$.
\end{abstract}

\begin{abstract}
Solar eclipse is one of the rare phenomenon. It occurs each 350 years in the same place. When the sun, the moon, and the earth in an inclined position then the eclipse occurs. In March $9^{\text {th }}$, 2016, Indonesia is the country which passed by the solar eclipse. Earth gravity measurement have been carried out during solar eclipse. This experiment conducted to verify the theory of gravity during an eclipse, that the gravity will decrease. The Microcomputer Based Laboratory (MBL) methode is used in this experiment. Based on the collected data, the gravity decrease during the eclipse. Before the eclipse, gravity measured as 9,78 $\mathrm{m} / \mathrm{s}^{2}$. At the first contact of moon and the sun the measured gravity is $9,45 \mathrm{~m} / \mathrm{s}^{2}$, meanwhile at the maximum partial eclipse the gravity measured as $8,87 \mathrm{~m} / \mathrm{s}^{2}$ and the last contact is $9,60 \mathrm{~m} / \mathrm{s}^{2}$. The lowest measured gravity is $8,87 \mathrm{~m} / \mathrm{s}^{2}$ which occurs at the maximum partial solar eclipse.
\end{abstract}

Kata kunci: gerhana matahari, percepatan gravitasi, microcumputer based laboratory

\section{Pendahuluan}

Pembelajaran fisika di sekolah maupun perguruan tinggi hendaknya bersentuhan langsung dengan fenomena alam yang ada. Sehingga pembelajaran fisika bisa lebih konkret, terlebih untuk anak-anak di sekolah menengah. Terkadang kita sebagai pendidik hanya menyampaikan apa yang ada di buku saja. Kita kurang mengeksplorasi fenomena alam yang terjadi untuk dikaitkan dengan teori fisika yang ada.

Ada banyak sekali fenomena alam yang bisa diamati salah satunya adalah gerhana matahari yang terjadi pada 6 maret 2016 silam. Indonesia merupakan satu-satunya negara yang dilintasi oleh jalur Gerhana Matahari Total (GMT) [I]. Dimulai dari Palembang, Bangka Belitung, hingga ke bagian Indonesia Timur, kota Poso dan Ternate [2]. Sisanya, hampir di setiap tempat bisa melihat gerhana matahari sebagian (GMS) dengan prosentase yang berbeda-beda.

Gerhana matahari merupakan peristiwa saat bulan melintas tepat diantara matahari dan bumi, mengakibatkan bayangan bulan akan jatuh dipermukaan bumi [3]. Ada banyak hal yang bisa diamati saat peristiwa ini terjadi. Mulai dari keadaan atmosfer, diameter bulan, jarak bulan dan matahari, pengaruh terhadap kapasitansi sel surya, pengaruh percepatan gravitasi, sampai perilaku hewan.

Dengan banyaknya hal yang bisa diamati, ditambah waktu pengulangan yang sangat lama, membuat fenomena ini amat ditunggu-tunggu oleh semua kalangan. Perlu diketahui bahwa GMT terjadi pada satu tempat yang sama setiap 350 tahun sekali [4].

Dalam penelitian ini, akan dikaji pengaruh dari GMT terhadap nilai gravitasi bumi. Secara teori, percepatan gravitasi bumi akan berkurang, karena saat peristiwa ini, 
bumi ditarik oleh dua gaya sekaligus dalam arah yang sama [5].

Ini merupakan salah satu cara untuk mendekatkan fenomena fisika terhadap teori fisika kepada para siswa. Siswa bisa diajak untuk melakukan suatu pengamatan kecil. Selain menikmati keindahan gerhana, siswa juga diminta untuk melakukan ekeperimen terkait salah satu topik fisika.

Apabila hal ini diterapkan, niscaya kemampuan fisika siswa bisa meningkat, karena yang mereka pelajari bukan hal yang abstrak lagi, namun suatu peristiwa yang riil terjadi. Model pembelajaran untuk seperti ini bisa digunakan model inquiry learning.

\section{Metode Penelitian/Eksperimen}

Pada perhitungan nilai percepatan gravitasi bumi, digunakan metode gerak jatuh bebas dengan sistem microcomputer based laboratory (MBL), dimana komputer difungsikan sebagai alat bantu untuk proses perekaman data. Desain alat eksperimen bisa disaksikan pada gambar I.
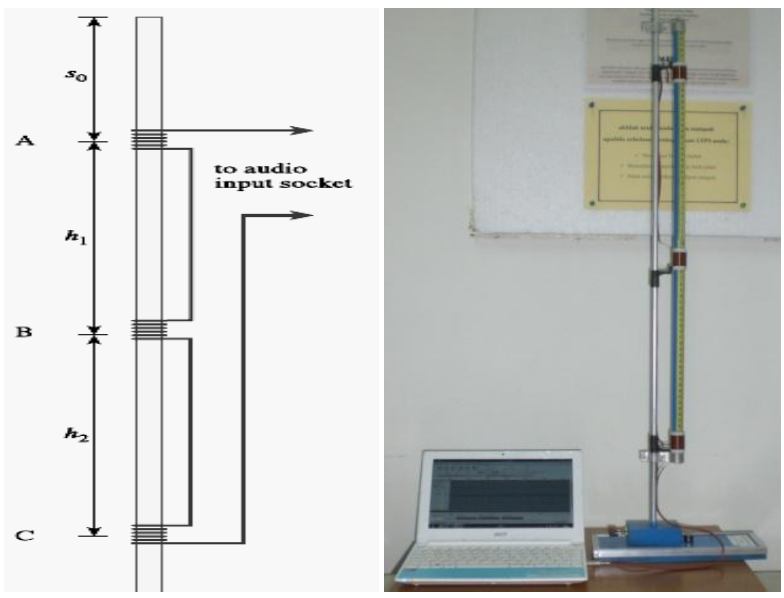

Gambar I. Desain alat pengambilan data [6]

Metode gerak jatuh bebas digunakan mengingat caranya yang sederhana. Cukup dengan menghitung waktu tempuh saat benda jatuh dan ketinggian, maka percepatan gravitasi bisa diperoleh. Perhitungan waktu pada penelitian ini menggunakan koil (lilitan) yang dihubungkan melalui soundcard laptop. Koil ini berfungsi seperti microphone. Jika dilewatkan magnet melalui koil ini, maka akan timbul induksi yang terekam sebagai pulsa di software Audacity. Contoh hasil rekaman data bisa dilihat pada gambar 2 .

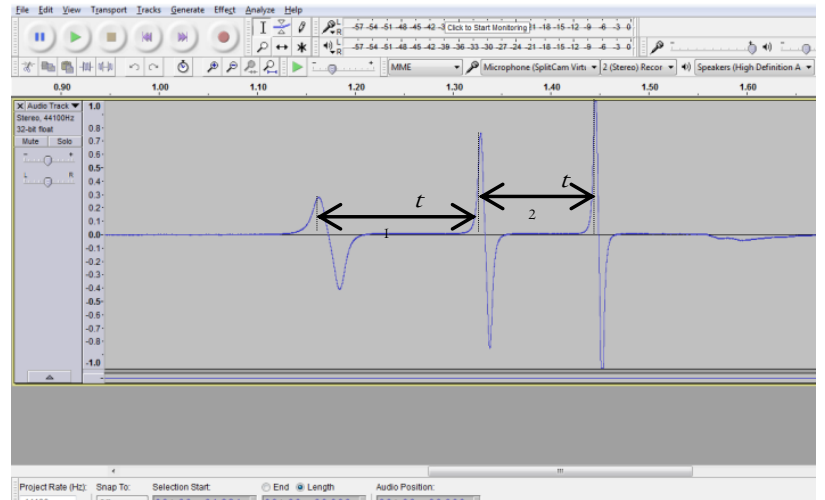

Gambar 2. Contoh ampilan pulsa pada Audacity

Tidak ada spesifikasi khusus magnet yang digunakan, sembarang magnet bisa digunakan. Jarak antara koil A dan B didefinisikan sebagai $h$ r sebesar $(0,29 \pm 0,05) \mathrm{m}$, waktu antar kedua koil ini merupakan $t$. Sedangkan jarak koil B dan $C$ merupakan $h 2$, sebesar $(0,36 \pm 0,05) \mathrm{m}$, dan waktunya t2. Menggunakan persamaan I, maka nilai gravitasi dapat dihitung.

$$
g=\frac{2\left(\frac{h_{2}}{t_{2}}-\frac{h_{1}}{t_{1}}\right)}{t_{1}+t_{2}}
$$

Pengukuran dilakukan secara berulang sebanyak sepuluh kali, untuk memperoleh nilai rata-rata yang baik.

Data diambil di wilayah Yogyakarta. Wilayah ini tidak dilalui GMT, melainkan Gerhana Matahari Sebagian dengan prosentase $81,46 \%[7]$.

Pengambilan data dilakukan pada 3 fase, fase yang pertama saat kontak pertama antara bulan dan matahari, fase kedua merupakan fase gerhana puncak, dan fase ketiga fase kontak terakhir. Tiap fase, pengambilan data dilakukan sebanyak sepuluh kali. Hasil ini akan dibandingkan dengan hasil ketika tidak terjadi gerhana. Fase-fase ini tampak pada gambar 3.

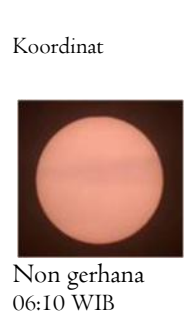

06:10 WIB
Universitas Ahmad Dahlan Yogyakarta

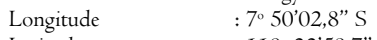

Latitude $\quad: 110^{\circ} 22^{\prime} 58,7^{\prime \prime} \mathrm{E}$

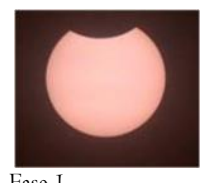

Fase I

06:30 WIB

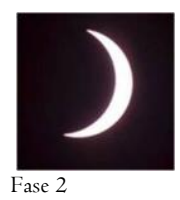

07:20 WIB

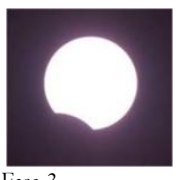

Fase 3 08:26 WIB
Gambar 3. Kronologi GMS di wilayah Kota Yogyakarta

\section{Hasil Penelitian dan Pembahasan}

Setelah dilakukan analisis pada data yang telah diperoleh, didapati bahwa nilai percepatan gravitasi 
mengalami penurunan selama proses gerhana. Ini bisa dilihat di tabel I.

Tabel I. Nilai percepatan gravitasi tiap fase

\begin{tabular}{lcccc}
\hline & $\begin{array}{c}\text { Non } \\
\text { gerhana }\end{array}$ & Fase I & Fase 2 & Fase 3 \\
\hline \hline $\begin{array}{l}\text { Percepatan } \\
\text { gravitasi } \\
\left(\mathrm{m} / \mathrm{s}^{2}\right)\end{array}$ & $9,80 \pm 0,16$ & $9,54 \pm 0,23$ & $8,87 \pm 0,33$ & $9,60 \pm 0,19$ \\
$\begin{array}{l}\text { Prosentase } \\
\text { penurunan }\end{array}$ & 0 & $2,65 \%$ & $9,45 \%$ & $2,00 \%$ \\
\hline
\end{tabular}

Untuk lebih memperjelas penurunan nilai gravitasi ini tabel I diplot dalam bentuk gambar seperti pada gambar 4.

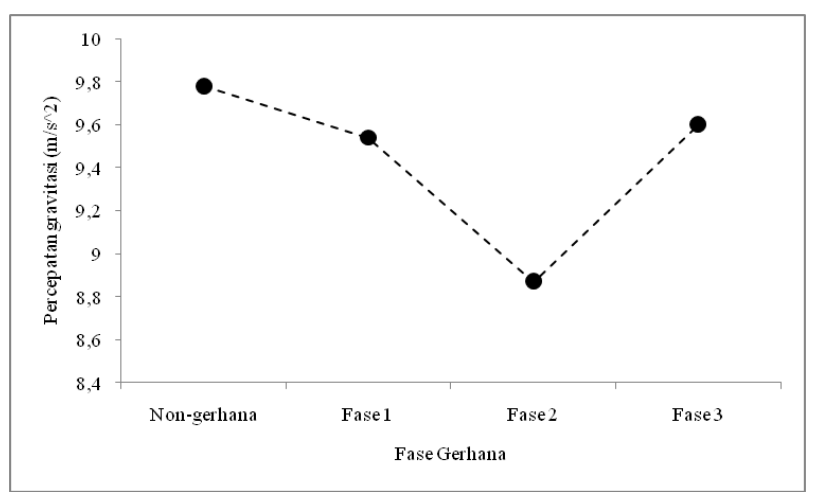

Gambar 4. Ploting percepatan gravitasi pada tiap fase gerhana

Penurunan paling banyak terjadi saat fase gerhana puncak, sampai 9,45\%. Ini terjadi saat matahari bumi dan bulan tepat berada pada satu garis lurus. Pada fase ini bumi ditarik oleh dua gaya gravitasi yang searah, yaitu gravitasi bumi-bulan dan bumi-matahari. Gaya ini searah dan saling menjumlahkan. Inilah yang mengakibatkan nilai percepatan gravitasi bumi berkurang. Percepatan gravitasi bumi di wilayah Kota Yogyakarta rata-rata sebesar $9,78 \mathrm{~m} / \mathrm{s}^{2}[8]$. Dari hasil eksperimen saat tidak terjadi gerhana diperolah hasil yang relatif sama, yaitu sebesar $9,80 \mathrm{~m} / \mathrm{s}^{2}$.

Fakta riil seperti inilah yang jarang dihadirkan ke dalam ruang kelas. Fenomena alam seperti ini biasanya kita cenderung untuk lebih menikmati keindahannya saja, jarang kita mencoba mengkaji bagaimana hukum fisika bekerja pada suatu fenomena alam. Hal ini menarik, jika kita mampu menghadirkannya dalam ruang-ruang kelas. Dimana suatu peristiwa alam bisa mempengaruhi besaran alam yang lain. Tentu ini akan memberikan pengalaman yang baru untuk siswa terkait pelajaran fisika.

Bahkan lebih jauh lagi, kita juga bisa mengkaitkan bahwa apa yang kita lakukan terhadap alam ini, pasti akan memberikan pengaruh terhadap alam itu sendiri, sekecil apapun itu.

\section{Kesimpulan}

Saat peristiwa gerhana matahari (GMS khususnya) terjadi penurunan nilai percepatan gravitasi bumi, yang semula $9,78 \mathrm{~m} / \mathrm{s}^{2}$, turun menjadi $9,5 \mathrm{~m} / \mathrm{s}^{2}$ saat mencapai puncak menjadi $8,8 \mathrm{~m} / \mathrm{s}^{2}$, kemudian berangsur kembali normal. Saat kontak terakhir tercatat percepatan gravitasi telah mengalami kenikan menjadi 9,6 m/ $\mathrm{s}^{2}$.

Hal ini terjadi karena saat itu bumi ditarik oleh dua gaya sekaligus yang searah. Gaya gravitasi bumi-bulan dan bumi-matahari. Ini bisa menjadi sebuah fakta baru yang bisa menambah khazanah pengetahuan tentang gejala alam dan efek yang ditimbulkannya.

\section{Ucapan Terimakasih}

Terimakasih penulis sampaikan kepada Tim Gerhana (Tiger) UAD atas fasilitas tempat pengamatan. Terimakasih juga disampaikan kepada Panitia Nasional Pengamatan Gerhana Matahari Total di bawah koordinasi LAPAN. Selain itu terimakasih juga disampaikan kepada Bapak Drs. Ishafit, M.Si., atas rancangan aparatusnya dan kepada Bapak Mustofa Ahyar, S.Pd. atas foto fase gerhananya.

\section{Kepustakaan}

[I] Kasmawati Saleh and Wahyu Purwaningsih, "Gerhana Matahari Total 2016," Majalah IOOO Guru, vol. IV, no. I, pp. 9-II, Januari 2016.

[2] BMKG. (2016, Februari) Lembaga Penerbangan dan Antariksa Nasional. [Online].

http://lapan.go.id/files_arsip/Gerhana_Matahari_Total_9_M aret_2016.pdf

[3] Avivah Yamani. (2016, April) Langit Selatan. [Online]. http://langitselatan.com/2014/04/28/mengenal-gerhanamatahari/

[4] Panitia Nasional. (2016) Universe Awareness Indonesia. [Online]. http://bosscha.itb.ac.id/unawe/wp-content/uploads/brosurgerhana-unawe.pdf

[5] Zainuddin, Mohd, Zambri et all, "Acceleration due to Gravity Changes during Solar Eclipse Phases", Proceeding of the 2011 IEEE International Conference on Space Science and Communication, pp. I70-I73, Juli 20II.

[6] S Ganci, "Measurement of $\mathrm{g}$ by means of the 'improper' use of sound card software: a multipurpose experiment," IOP Sciences, vol. 43, no. 3, pp. 297-300, Mei 2008.

[7] Nasa. (2016) National Aeronautics and Space Administration website. [Online].

http://eclipse.gsfc.nasa.gov/SEgoogle/SEgoogle200I/SE20I6 Mar09Tgoogle.html

[8] Dwi Martini dan Oktova, "Penentuan Modulus Young Kawat Besi dengan Percobaan Regangan”, Berkala Fisika Indonesia, vol. 2, no. I, pp. I-I4, Juli 2009. 